\title{
Food Hygiene for Food Handlers
}




\section{Related Macmillan titles}

The New Catering Repertoire:

Volume 1 Aide-Mémoire du Chef

Volume 2 Aide-Mémoire du Restaurateur et Sommelier H L Cracknell and $G$ Nobis

Practical Professional Catering H L Cracknell, G Nobis and R Kaufmann

Practical Professional Cookery H L Cracknell and R Kaufmann

Practical Professional Gastronomy H L Cracknell and G Nobis

Managing Food Hygiene Nick Johns

Hospitality Management Sally Messenger and Humphrey Shaw

Healthy Eating Rob Silverstone

In the Mastercraft series, published with the Hotel and Catering Training Company

Customercraft: Keeping the Customer Satisfied Roy Apps

Foodcraft 1: The Dry Processes

Foodcraft 2: The Wet Processes

Mastercraft 1: Working in the Hotel and Catering Industry Sally Messenger Mastercraft 2: Health, Hygiene and Safety in the Hotel and Catering Industry Marion Kenber and William McCurrach

Please write to The Sales Department, The Macmillan Press for details of other Mastercraft titles, other Macmillan textbooks and the current Vocational Education catalogue. 


\section{Food Hygiene for Food Handlers}

Jill Trickett

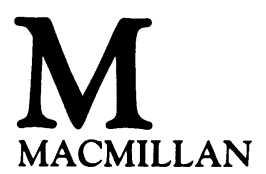




\section{ISBN 978-0-333-55574-3 ISBN 978-1-349-80602-7 (eBook)}

DOI 10.1007/978-1-349-80602-7

\section{(C) Jill Trickett 1992}

Reprint of the original edition 1992

All rights reserved. No reproduction, copy or transmission of this publication may be made without written permission.

No paragraph of this publication may be reproduced, copied or transmitted save with written permission or in accordance with the provisions of the Copyright, Designs and Patents Act 1988, or under the terms of any licence permitting limited copying issued by the Copyright Licensing Agency, 90 Tottenham Court Road, London W1P 9HE.

Any person who does any unauthorised act in relation to this publication may be liable to criminal prosecution and civil claims for damages.

First published 1992 by

THE MACMILLAN PRESS LTD

Houndmills, Basingstoke, Hampshire RG21 2XS

and London

Companies and representatives

throughout the world

ISBN 978-0-333-55574-3

A catalogue record for this book is available from the British Library.

Typeset by Wearset, Boldon, Tyne and Wear

$\begin{array}{llllllllll}10 & 9 & 8 & 7 & 6 & 5 & 4 & 3 & 2 & 1\end{array}$

01009998979695949392

The author and publishers wish to acknowledge, with thanks, the following photographic sources: British Gas, pages 56, 101; British Pest Control Association, page 74 bottom left; Jim Brownbill, pages 49, 59 right, 66; Ron Chapman, page 8; Dawson MMP Ltd, page 69; Electronic Temperature Instruments Ltd, page 35; F I Image, page 27; Foster Refrigerator UK Ltd, cover; Graham Photography, page 68; Imperial Machine Co (peelers) Ltd, page 59 left; E. Leitz (Instruments) Ltd, page 3; Nuffield Foundation, page 74 top right; Valerie Randall, pages 6, 20, 58, 60; Rentokil Ltd, pages 74 top left, 74 bottom right, 77 bottom; Science Photo Library, page 10; David Wiltshire, page 77 top.

The author and publishers wish to acknowledge the following copyright holders: Liquid Crystal Devices Ltd for the reproduction of a refrigerator thermometer; The Royal Institute of Public Health \& Hygiene and The Royal Society of Health for examination questions; Signs and Labels Ltd for the reproduction of various signs.

The publishers have made every effort to trace the copyright holders, but where they have failed to do so they will be pleased to make the necessary arrangements at the first opportunity. 


\section{Contents}

1 Micro-organisms and Food Poisoning 1

Micro-organisms 2

Other causes of poisoning associated with food 7

2 Bacterial Growth 10

Reproduction 10

Conditions necessary for bacterial growth 11

3 Food Contamination 18

Sources of contamination $\quad 18$

Cross-contamination $\quad 22$

4 Personal Hygiene for Food Handlers 25

Hand-washing 25

Protective clothing $\quad 26$

Jewellery $\quad 26$

Smoking 27

Nose and mouth 28

Cuts, boils and septic spots $\quad 28$

Reporting illness 29

5 Correct Food Handling Procedures 32

Thawing food 33

Cooking food $\quad 35$

Cooling food $\quad 36$

Reheating food $\quad 37$

Microwave ovens $\quad 38$

6 Food Storage 41

Heat treatment of foods 41

Date marking $\quad 42$

Storage of food at low temperatures $\quad 42$

Storage of food at room temperature $\quad 49$

Storage of food at high temperatures $\quad 51$ 
7 Kitchen Design and Equipment 53

The industrial kitchen $\quad 53$

$\begin{array}{ll}\text { The domestic kitchen } & 60\end{array}$

8 Cleaning and Disinfection 63

Cleaning schedules $\quad 63$

Cleaning materials $\quad 64$

The cleaning process $\quad 67$

9 Pest Control 73

Problems associated with pests $\quad 73$

Prevention $\quad 75$

Signs of infestation $\quad 76$

Control of pests $\quad 76$

10 Food Hygiene Legislation $\quad 80$

Enforcement of legislation $\quad 81$

The Food Hygiene (General) Regulations 1970 and
The Food Hygiene (Amendment) Regulations 1990

The Food Safety Act $1990 \quad 82$

11 Bacteria that Commonly Cause Food Poisoning 85

Identifying the type of food poisoning 86

$\begin{array}{ll}\text { Salmonella } & 87\end{array}$

Campylobacter $\quad 89$

Clostridium perfringens $\quad 90$

Staphylococcus aureus $\quad 91$

Bacillus cereus $\quad 93$

Listeria monocytogenes $\quad 94$

12 The Prevention of Food Poisoning 97

Common faults in food preparation 98

A strategy for the prevention of food poisoning 102

$\begin{array}{ll}\text { Examination Questions } & 104\end{array}$

$\begin{array}{ll}\text { Answers } & 115\end{array}$

$\begin{array}{ll}\text { Index } & 118\end{array}$ 